\title{
CHEMINIŲ ŠVEITIKLIŲ POVEIKIS, SPRENDŽIANT BRANDŽIOS RANKŲ ODOS PROBLEMAS
}

\author{
Loreta Valatkevičienė ${ }^{1}$, Vaiva Vaikšnorienė ${ }^{1}$, Žaneta Mickienè ${ }^{1}$, Sandrija Čapkauskiené $\dot{e}^{1,2}$ \\ ${ }^{1}$ Kauno kolegijos Kosmetologijos katedra, ${ }^{2}$ Lietuvos sporto universiteto \\ Taikomosios reabilitacijos ir biologijos katedra
}

Raktažodžiai: cheminiai šveitikliai, brandi rankų oda, senejjimas

\section{Santrauka}

Senejjimo procesas sukelia tiek natūralius, tiek ir lètinius, ultravioletinių spindulių sukeltus rankų odos pokyčius. Stebimi odos struktūros ir pigmentacijos kitimai, odos elastingumo praradimas, minkštųu audinių atrofija, kuri sąlygoja kaulų ir sausgyslių atsikišimus bei venų išryškejjimą. Siekiant atgaivinti brandžią odą, viena iš vis dažniau siūlomų priemonių - tai cheminiai šveitikliai. Cheminiai šveitikliai drèkina odą, švelnina raukšles, padidina elastingumą. Tyrimo tikslas: įvertinti cheminių šveitiklių poveikị sprendžiant brandžios rankų odos problemas. Tyrimo metodai: 1.Odos būklès ịvertinimas diał gnostiniu aparatu „Skin analyzer Soft plius“ 2. Ches minių šveitiklių procedūros. Buvo atliktas 4 procedūrų kursas: dešinei rankai naudotas rūgštinis Pieno šveitiklis, kairei rankai - Jessner rūgštinis šveitiklis. Tyrime dalyvavo vienuolika 50-60 metų amžiaus moterų. Rezultatai: atlikus skirtingas cheminio šveitimo procedūras, buvo nustatyta, kad brandžios rankų odos drègmè padidèjo - dešinès rankos nuo 9,5, proc. iki 21,4 proc., kairés rankos - nuo 19,3 proc. iki 38,5 proc. $(p<0,05)$. Abiejų rankų odos elastingumas pagerejjo nuo 48,7 iki 50,00 proc. Raukšliu gylis reikšmingai sumažèjo: dešinès rankos nuo 8,9 $\mathrm{mm}$ iki 5,2 mm, kairès rankos - nuo 8,2 mm iki 5,9 $\mathrm{mm}(\mathrm{p}<0,05)$. Brandžios rankų odos pigmentacija ir keratino lygis po rūgštinių šveitimo procedūru kurso taip pat reikšmingai sumažèjo $(p<0,05)$. Lyginant cheminio šveitimo procedūrų poveikị kairei ir dešinei rankoms, reikšmingo skirtumo nebuvo $(\mathrm{p}>0,05)$. Tyrimo išvados: atlikus skirtingų cheminių šveitiklių - Pieno ir Jessner rūgščių - procedūras ant brandžios rankų odos, nustatyta, kad drėgmé pa- didejjo, elastingumas pagerèjo, odos raukšlių gylis, pigmentacija ir keratino lygis reikšmingai sumažèjo. Skirtingų rūgštinių šveitiklių procedūrų poveikis kairei ir dešinei rankoms buvo vienodas, nes visi tirti rodikliai - drègmé, elastingumas, raukšlių gylis, pigmentacija ir keratino lygis - nesiskyrè.

\section{Ivadas}

Odos senejjimą skatina tokie veiksniai kaip genetika, aplinkos sąlygos, hormoniniai pokyčiai, metaboliniai procesai. Visi šie veiksniai sąlygoja liekamuosius odos struktūros, funkcijos ir išvaizdos pakitimus [1]. Išorinis rankų senejjimas, nulemtas fotosenejjimo, chemikalų naudojimo, rūkymo, apima dermos bei epiderminius sluoksnius ir sąlygoja negilių raukšlių atsiradimą, senatvinę keratozę, pigmenatacijos pokyčius $[2,3]$. Su amžiumi atsiranda tokie spalviniai odos pakitimai, kaip geltonesnè rankų oda, dèmès, hormoninių pakitimų sukelta melasma [1]. Ultravioletinių spindulių poveikis sąlygoja melanino, atsakingo už odos spalvą, suaktyvejimą. Per didelis kiekis susidariusio ir susikaupusio melanino sąlygoja odos spalvos pokyčius, raukšlių atsiradimą bei odos senėjimą [4]. Vidiniai senėjimo pokyčiai, veikdami gilesnius audinius, sumažina odos elastingumą, suplonina odą [5,6]. Elastino skaidulų pažeidimai sąlygoja odos tamprumo mažèjimą. Elastinas - ekstraląstelinio matrikso baltymas, formuojantis elastines skaidulas dermoje ir tokiu būdu didinantis odos elastingumą. Viena iš priežasčių, sukelianti senèjimo procesus, tai akytujų elastinių skaidulų atsiradimas jungiamajame audinyje. Elastinių skaidulų distrofija ir suardymas sąlygoja nelygumų bei raukšlių formavimąsi odos paviršiuje [7]. Senstanti rankų oda taip pat tampa sausa ir žvynuota. Tai paaiškinama odos lipidinio barjero degeneracija arba jo praradimu. Šis multifaktorinis procesas ịvyksta dalinai dèl nepakankamo raginio sluoksnio lipidų lygio ir sumažejusio epidermio baltymo - filagrino - koncentracijos [8,9]. Raginio sluoksnio lipidai suteikia tvirtumo ir apsaugo nuo drègmés praradimo 
[9], o jų struktūros pokyčiai lemia odos bilipidinio paviršinio sluoksnio mažèjimą [10]. Apie 50-uosius gyvenimo metus endokrininès sistemos pokyčiai sukelia epiderminio vandens jungiamosios funkcijos silpnejjimą, o tai sąlygoja statinių raukšlių ịsitvirtinimą bei ilgalaikị odos lipidinio barjero suardymą $[5,6]$. Todèl stebima minkštųu audinių atrofija, kuri sąlygoja kaulų ir sausgyslių atsikišimus bei venų išryškèjimą [3].

Senstanti rankų, kaip ir veido, oda reikalauja kombinuotos priežiūros, siekiant optimalaus rezultato [3,11]. Todèl rankų atjauninimo procedūros tampa vis populiaresnès. Be rankų masažo, injekcinių, elektrostimuliacinių procedūrų, vis dažnesnis tampa cheminis šveitimas. Cheminis švei-

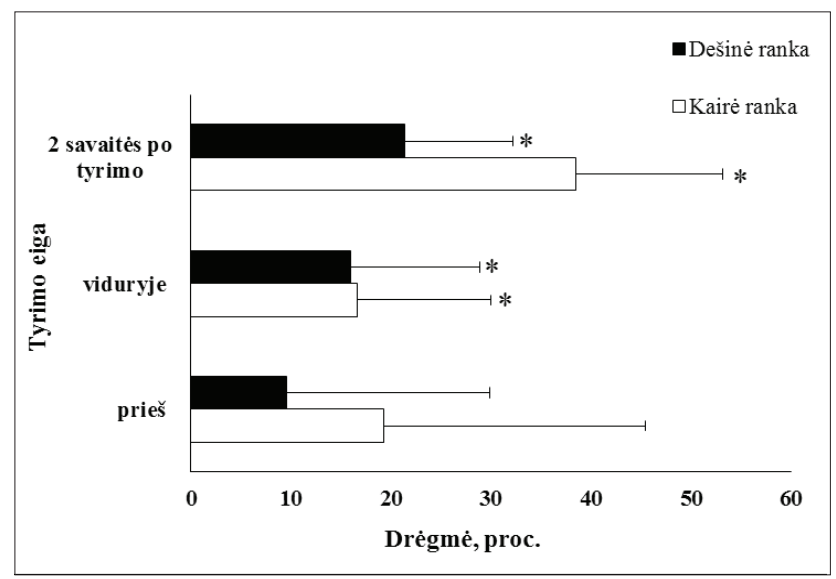

1 pav. Dešinės ir kairès rankų drėgmės pokyčiai po rūgštinių šveitimo procedūrų

${ }^{*} p<0,05$ - statistiškai reikšmingas skirtumas lyginant su pradine reikšme, buvusia prieš tyrima

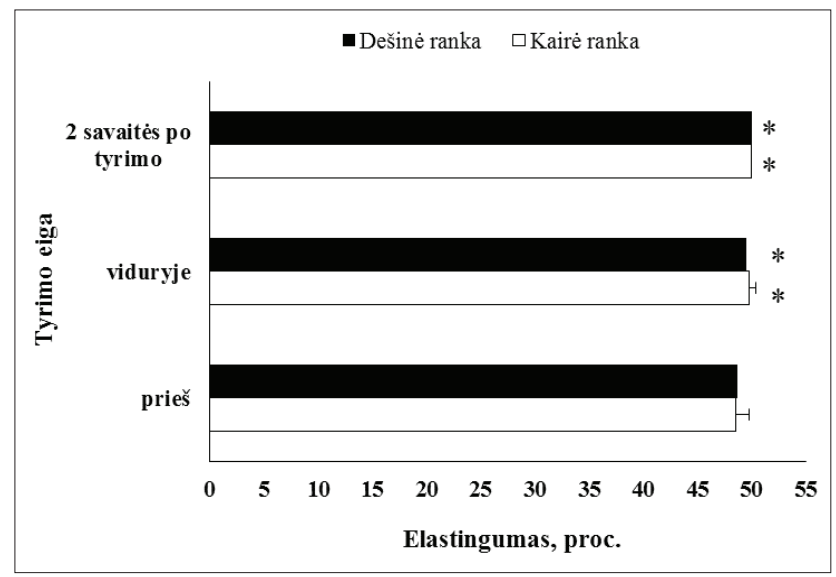

2 pav. Dešinės ir kairès rankų elastingumo pokyčiai po rūgštinių šveitimo procedūru

* $p<0,05$ - statistiškai reikšmingas skirtumas lyginant su pradine reikšme, buvusia prieš tyrima timas - tai metodas, sąlygojantis chemini tam tikrų odos sluoksnių pašalinimą. Rūgščių cheminių elementų poveikyje suardyti odos sluoksniai pasišalina per kelias dienas, užtikrina epidermio bei dermos atsistatymo mechanizmus. Suardymo gylis labai priklauso nuo cheminio elemento sudèties ir jo koncentracijos $[6,11]$. Cheminiai pilingai drèkina odą, šalina laisvuosius radikalus, padidina epidermio pralaidumą vitaminams ir depigmentuojantiems elementams, stimuliuoja fibroblastų gamybą, švelnina raukšles, padidina elastingumą [6].

Panašaus pobūdžio tyrimų nèra daug - Lietuvoje nèra publikuoto nei vieno mokslinio straipsnio šia tema, užsie-

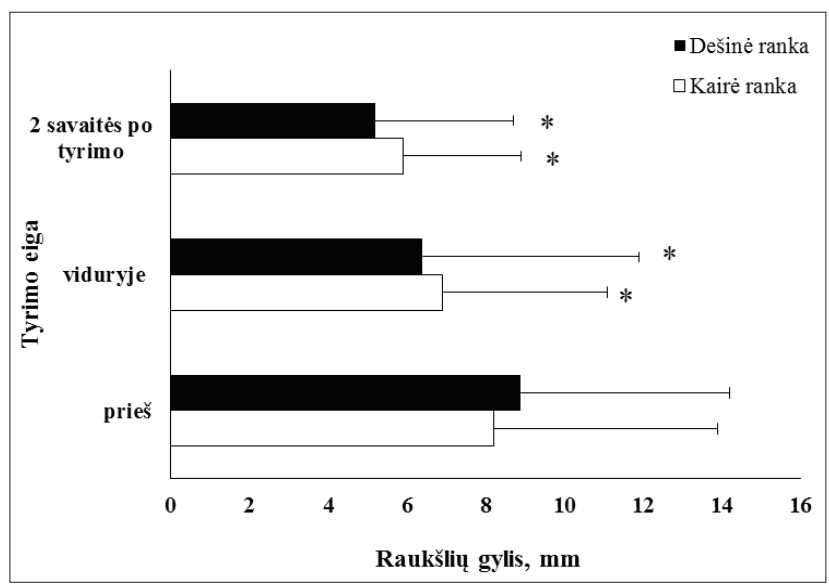

3a pav. Dešinės ir kairès rankų raukšlių gylio pokyčiai po rūgštinių šveitimo procedūrų taikymo

* $p<0,05$ - statistiškai reikšmingas skirtumas lyginant su pradine reikšme, buvusia prieš tyrima
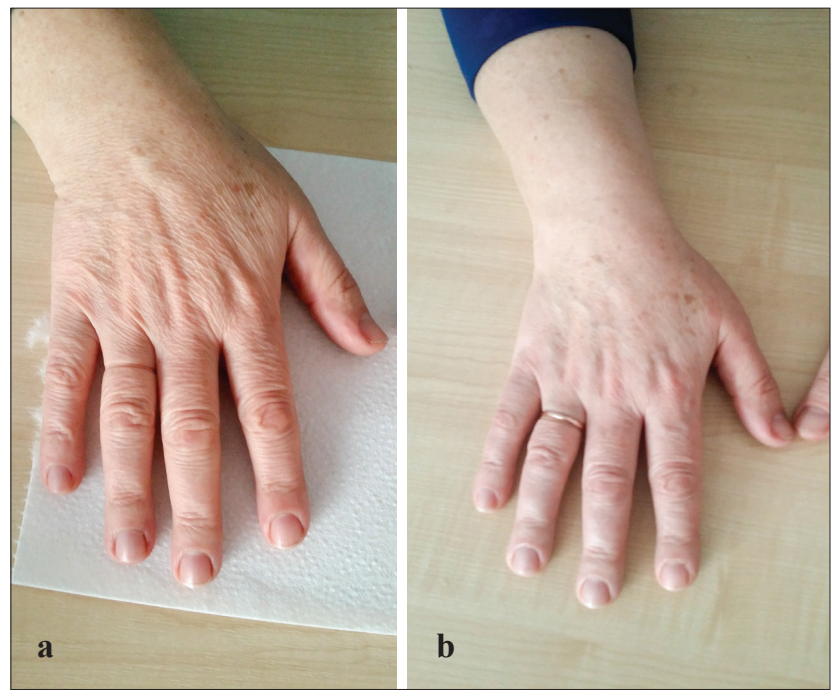

3b pav. Rankų raukšlių gylio pokyčiai prieš (a) ir po (b) rūgštinių šveitimo procedūrų taikymo $(\mathrm{p}<0,05)$ 
nio literatūroje taip pat nedaug mokslinių tiriamujų publikacijų apie senstančią rankų odą bei jos atjauninimą.

Darbo tikslas - įvertinti cheminių šveitiklių poveiki sprendžiant brandžios rankų odos problemas.

\section{Tyrimo medžiaga ir metodai}

Tyrime dalyvavo vienuolika 50-60 metų amžiaus moteł rų. Tiriamujų atrankos kriterijai: amžius, panašios gyveniv mo sąlygos, darbinè veikla (biuro darbuotojos, destytojos, referentès), panašus rankų odos senejjimo laipsnis, problemų pobūdis - sumažějęs elastingumas, išsausẻjimas, raukšlès, hiperpigmentacija. Tyrime negalèjo dalyvauti moterys, kurioms yra ar buvo diagnozuoti piktybiniai odos navikai, bẻrimai, tokie kaip pūslelinè, dermatitas, infekcinès ligos. Visoms tiriamosioms buvo atliktas 4 cheminių šveitiklių procedūrų kursas kas dvi savaites. Dešinei rankai naudotas „Lactic-peel“ rūgštinis pieno šveitiklis $(30 \%, \mathrm{pH} 1,8)$, kairei rankai - „Jessner“ rūgštinis šveitiklis (14\% salicilo rūgšties, $14 \%$ pieno rūgšties, $8 \%$ citrinų rūgšties; $\mathrm{pH}$ 1,5). Viso tyrimo metu kiekvienos rankos plaštakai buvo naudojamos tik vienos rūšies cheminis šveitiklis. Pirmujų procedūrų trukmè buvo 5 ir 7 min., paskutiniuju - $10 \mathrm{~min}$. Svarbu buvo, kad prieš odos būklès diagnostiką tiriamosios bent dvi valandas nebūtų tepusios rankų kremu. Odos būi klès ịvertinimas diagnostikos aparatu „Skin analyzer Soft plius" atliktas prieš procedūrų kursą, ịpusèjus jam (po 2 procedūrų) ir praèjus 2 savaitèms po paskutinès, ketvirtosios procedūros. Buvo ịvertinti tokie rankų odos būklès parametrai, kaip drègmé, elastingumas, keratino lygis, raukšlių gylis, pigmentacija.

Duomenų statistinė analizė atlikta naudojant SPSS 22.0 (Statistical Package for Social Sciences) statistinès programos paketą. Skaičiavimams buvo panaudoti aprašomosios statistikos ir dispersinès analizès rezultatai, kurie pateikiami skaitine ir procentine išraiškomis bei grafiniu pavidalu. Norint nustatyti, ar tiriamų kiekybinių ir kokybinių požymių reikšmių skirstiniai populiacijoje yra lygūs, buvo skaičiuojamas neparametrinis Vilkoksono kriterijus, kuris leido ivertinti, ar pasikeite ir kaip pasikeitė rankų oda panaudojus AHA rūgštinius šveitiklius. Tiriant, ar kokybinių požymių reikšmių proporcijos dviejose nepriklausomose imtyse yra lygios, buvo taikomas chi kvadrato požymių homogeniškumo kriterijus. Rodiklių skirtumai laikyti statistiškai reikšmingi, kai $\mathrm{p}<0,05$.

\section{Tyrimo rezultatai}

Eksperimento metu taikytos rūgščių šveitiklių procedūros padidino dešinès ir kairès rankos drègmę (1 pav.). Dešnès rankos drègmès vidurkis padidèjo nuo $9,5 \pm 20,4$ proc. iki $21,4 \pm 10,8$ proc. $(\mathrm{p}<0,05)$, kairès rankos - nuo $19,3 \pm 26,1$ proc. iki $38,5 \pm 14,7$ proc. $(\mathrm{p}<0,05)$. Vertinant drègmès pokytị tarp kairès ir dešinès rankų, statistiškai reikšmingo skirtumo nerasta - taikytų rūgštinių šveitimo procedūrų poveikis buvo vienodas abiem rankoms $(\mathrm{p}>0,05)(1 \mathrm{pav}$.).

İvertinus rankų odos elastingumą po atliktų rūgštinių procedūrų, dešinès rankos elastingumo vidurkis padidèjo nuo $48,7 \pm 1,2$ iki $50,0 \pm 0$ proc. $(p<0,05)$, kairès rankos elastingumas padidèjo nuo $48,5 \pm 1,3$ iki $50,0 \pm 0$ proc. $(p<0,05)$. Tarp kairès ir dešinès rankos šis rodiklis statistiškai reikšmingai nesiskyrè ( $p>0,05)$ ( 2 pav.).

Rūgštiniai šveitikliai turejo teigiamą poveikị dešinès ir kairès rankos raukšlių gyliui ( $3 \mathrm{a}$ ir $3 \mathrm{~b}$ pav.). Dešinès rankos raukšlių gylis sumažèjo nuo $8,9 \pm 5,3 \mathrm{~mm}$ iki $5,2 \pm 3,5$ $\mathrm{mm}(\mathrm{p}<0,05)$, kairès rankos - nuo $8,2 \pm 5,7 \mathrm{~mm}$ iki $5,9 \pm 3$ $\mathrm{mm}(\mathrm{p}<0,05)$. Vertinant raukšlių gylio pokytị tarp kairès ir dešinès rankos, statistiškai reikšmingo skirtumo nerasta $(\mathrm{p}>0,05)$.

Rankų odos pigmentacija (4 pav.), panaudojus rūgštinių šveitiklių procedūras, taip pat sumažejo - dešinès rankos nuo $2,4 \pm 0,7$ iki $1,6 \pm 0,7$ sąlyginių vienetų $(\mathrm{p}<0,05)$, kairès rankos - nuo 2,4 $\pm 0,5$ iki $1,5 \pm 0,7$ sąlyginių vienetų $(\mathrm{p}<0,05)$. Dešinès rankos odos pigmentacijos pokytis buvo $-2,3$ proc. $(\mathrm{p}<0,01)$, kairès rankos pokytis buvo $-2,9(\mathrm{p}<0,01)$, o tarp abiejų rankų pokyčio dydis buvo $-0,7$ ( $>0,05)$. Todèl, lyginant kairès ir dešinès rankos pigmentacijos pasikeitimą, galime teigti, kad rūgštinių šveitimo procedūrų poveikis buvo vienodas abiem rankoms ( $>00,05)$.

Ivertinus rankų odos keratino lygio (5 pav.) pokyčius eksperimento metu ir jam pasibaigus, buvo užfiksuotas reikšmingas šio rodiklio sumažèjimas - dešinės rankos nuo $2,4 \pm 0,7$ iki $1,36 \pm 0,5$ sąlyginių vienetų $(\mathrm{p}<0,05)$, kairès nuo $2,2 \pm 0,8$ iki $1,2 \pm 0,4$ sąlyginių vienetų $(\mathrm{p}<0,05)$. Dešiz nès rankos keratino lygio pokytis buvo $-2,6$ proc. $(p<0,01)$, kairés rankos pokytis buvo $-2,5(\mathrm{p}<0,05)$, tarp abiejų ranku pokyčio dydis buvo $-1(\mathrm{p}>0,05)$. Tad, lyginant kairès ir dešinès rankos keratino lygio pasikeitimą, galime teigti, kad rūgštinių šveitimo procedūrų poveikis buvo vienodas abiem rankoms $(\mathrm{p}>0,05)$.

Apibendrinant šio tyrimo rezultatus galima teigti, jog jie bus naudingi ateityje atliekant panašaus pobūdžio tyrimus, kadangi gautus rezultatus jau bus su kuo palyginti. Vis dèlto būtų tikslinga ši tyrimą pakartoti didesne imtimi, itraukiant tam tikrus gyvenimo kokybès klausimus, patobulinti taikomus tyrimo metodus, taip pat procedūras atlikti ilgesnị laiką.

\section{Išvados}

1. Atlikus skirtingų cheminių šveitiklių - pieno ir Jessner rūgščių - procedūras ant brandžios rankų odos, nusta- 


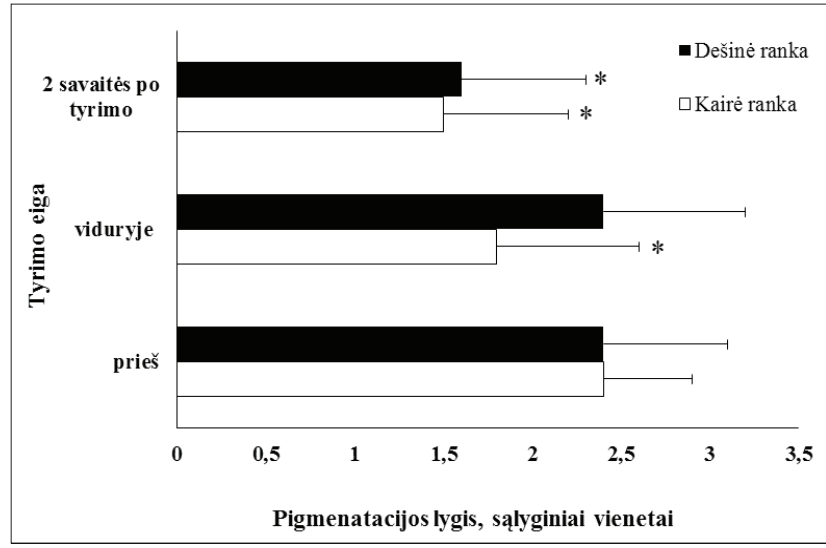

4 pav. Dešinès ir kairès rankų pigmentacijos pokytis po rūgštinių šveitimo procedūrų $(\mathrm{p}<0,05)$

$* p<0,05$ - statistiškai reikšmingas skirtumas lyginant su pradine reikšme, buvusia prieš tyrima

tyta, kad drègmè sumažèjo, elastingumas pagerèjo, odos keratino lygis, raukšlių gylis ir pigmentacija sumažèjo.

2. Skirtingų rūgštinių šveitiklių procedūrų poveikis kairei ir dešinei rankoms buvo vienodas, nes visi tirti rodikliai - drègmé, elastingumas, raukšlių gylis, pigmentacija ir keratino lygis nesiskyrè.

\section{Literatūra}

1. Callaghan TM, Wilhelm KP. Review of ageing and an examination of clinical methods in the assessment of ageing skin. Part I: Cellular and molecular perspectives of skin ageing international. Journal of Cosmetic Science 2008; 30:313-322 http://dx.doi.org/10.1111/j.1468-2494.2008.00454.x

2. Shamban AT. Combination hand rejuvenation procedures. Aesthet Surg J. 2009; 29(5):409-13. doi: 10.1016/j.asj

3. Riyaz FR, Ozog D. Hand rejuvenation. Semin Cutan Med Surg 2015;34(3):147-52. doi: 10.12788/j.sder.2015.0172 http://dx.doi.org/10.12788/j.sder.2015.0172

4. Herrling T, Jung K, Fuchs J. The important role of melaninas protector against free radicals in skin. SOFW Journal 2007;133:26-32.

5. Herman H, Roszkowska MR, Graca UK. Skin care during the menopause period: noninvasive procedures of beauty studies. Postep Derm Alergol 2013;6:388-395. DOI: 10.5114/ pdia.2013.39430 http://dx.doi.org/10.5114/pdia.2013.39430

6. Roy A, Sahu RK, Matlam M, Deshmukh VK, Dwivedi J, Jha AK. In vitro techniques to assess the proficiency of skin care cosmetic formulations. Pharmacognosy Reviews. 2013; Vol 7, Issue 14

7. Dayan N. Skin ageing handbook. An integrated approach to biochemistry and product development. William Andrew, 2008.

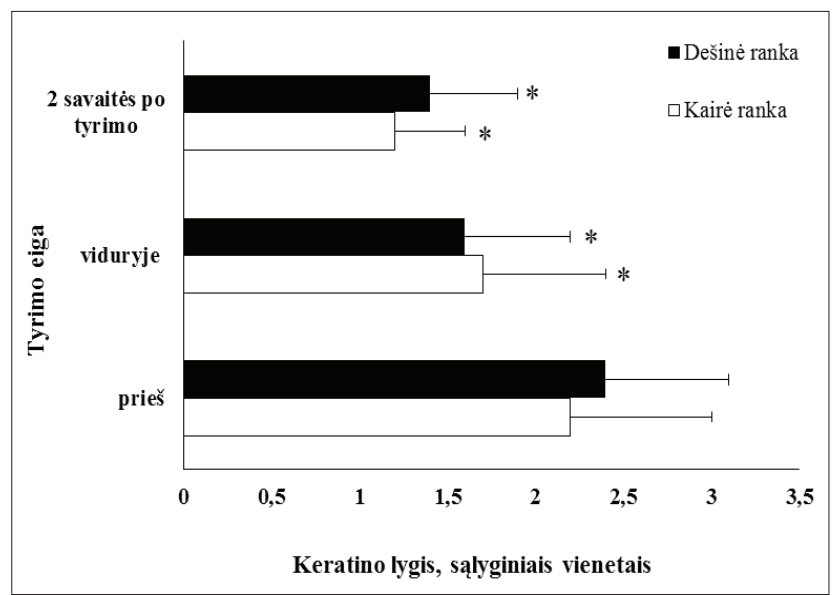

5 pav. Dešinės ir kairès rankų odos keratino pokytis po rūgštinių šveitimo procedūru $(\mathrm{p}<0,05)$

* $p<0,05$ - statistiškai reikšmingas skirtumas lyginant su pradine reikšme, buvusia prieš tyrima

8. O'Regan GM, Sandilands A, McLean WH, Irvine AD. Filaggrin in atopic dermatitis. J Allergy Clin Immunol 2009; 124 (3 Suppl 2): R26.doi:10.1016/j.jaci.2009.07.013

http://dx.doi.org/10.1016/j.jaci.2009.07.013

9. Draelos ZD. Cosmetic dermatology. Products and procedures. Wiley-Blackwell; 2010.

10. Barel EO, Paye M, Maibach HI. Handbook of cosmetic science and technology. Third Edition. NY 10017; 2009.

11. Fischer EC, Perosino E, Poli F, Viera M.S, Dreno B. Chemical peels in aesthetic dermatology: an update 2009. Journal of European Academy of Dermatology and Venorology 2010;24:281-292.

http://dx.doi.org/10.1111/j.1468-3083.2009.03409.x

\section{THE EFFECT OF CHEMICAL PEELS ON AGEING HANDS SKIN}

\section{Valatkevičienė, V. Vaikšnorienė, Ž. Mickienė,} S. Čapkauskienė

Key words: chemical peels, mature hands skin, ageing.

Summary

The ageing process causes both natural as well as chronic, ultraviolet light-induced hands skin changes. Changes of skin texture and pigmentation, reduction in skin elasticity, soft tissue atrophy, loss of volume and visible wrinkles formation are well characterized features of ageing skin. In order to revitalize mature skin, one of the increasingly proposed measures are chemical peels. Chemical peels moisturizes the skin, smoothe wrinkles, increase elasticity. The aim was to evaluate the effect of chemical peels on ageing hands skin. Research methods: 1 . Hands skin evaluation with the diagnostic apparatus ,,Soft Skin Analyzer Plus; 2. Chemical peels procedures. It was carried out 4 procedures course: Lactic acid peel was used on the right-hand, Jessner acid peel - on left hand. Eleven, 50-60 year-old women participated in this study. Results: different chemical peels increased the humidity of mature hands 
skin compared to baselin - the increment of the right arm was from 9.5 percent. to 21.4 percent., of the left arm - from 19.3 percent. to 38.5 percent. $(p<0.05)$. Skin elasticity improved from 48.7 to 50.00 percent. for both hands. Wrinkle depth was significantly reduced: decline of the right arm was from $8.9 \mathrm{~mm}$ to $5.2 \mathrm{~mm}$, of the left arm - from $8.2 \mathrm{~mm}$ to $5.9 \mathrm{~mm}(\mathrm{p}<0.05)$. Ageing hands pigmentation and keratin level also decreased $(\mathrm{p}<0.05)$. Comparing chemical peeling procedures on the left and the right hands, there were no significant difference of all indexes ( $p>0.05)$. Conclusions: different chemical peels - Lactic acid and Jessner - increased ageing hands skin humidity, improved elasticity and depth of the wrinkles, declined pigmentation and keratin levels. But different chemical peels effect for left and right hands was similar, because all the investigated indexess - moisture, elasticity, depth of wrinkles, pigmentation and keratin level - didn't differ between the hands ( $p>0.05)$.

Correspondence to: capkauskiene@gmail.com

Gauta 2016-09-27 